\title{
Jump Rope Games Modification: Enhancing Children's Motor and social skills
}

\author{
Heppy Zakiatun Nissa, Mustaji, Hendratno \\ Universitas Negeri Surabaya \\ Surabaya, Indonesia \\ Email: heppyzanissa@gmail.com
}

\begin{abstract}
Physical activities are essential elements that allow children to enhance their developments especially through activities based on traditional games. Jump rope games is a physical game which is modified by traditional games that promote early motor and social skills in kindergarten aged 5-6 years in Kindergarten DWP Randegansari. This research aimed to redesign the traditional jump rope games into the games that developed early motor and social skills. This research used Analyze, Design, Development, Implementation and Evaluation model with 28 children aged 5-6 years as the subjects. It used observation, interview, questionnaire and documentation to collect the research data. The result of this research is that the jump rope games modification has potential to enhance motor and social skills in group B kindergarten effectively.
\end{abstract}

Keywords-jump rope games modification; motor skills; social; children

\section{INTRODUCTION}

Every child has the same potential for growth. Various aspects of child development which are stimulated properly will help children go through future challenges with a more complex life. The future presents complex issues demands to healthy physical state and good mobility. Stimulation on motor can foster children to develop optimally, adopt agile, flexible, and powerful in performing a range of activities (Suryana, 2016).

In daily activities, motor skill used by children to move and play. [1] stated that the development of motor is all movements performed by a growing body of maturity and control the motion of the body. Motor development is crucial to honed early because it relates to the ability of the move which is the daily activities of human beings. Particularly in early childhood, children use a lot of motor ability especially gross to perform motor activities such as walking, running, skipping and other motor motion capabilities. They are doing as an effort to learn from their surroundings through the exploration of movement. This ability is growing rapidly from an early age and this is an opportunity for educators to maximize the potential of the children's motor skills [2]

Making children love to move will be better when they exist at an early age. Wijaya (2009) stated that childhood is referred to as the ideal time to learn the motor skills. At this age, children have a body that is still pliable and flexible, easy to learn new things, more likely to dare to dabble, like the repetition and children have more time to learn the motor skills especially a gross motor. Motor skills include whole body movement or part that includes endurance, speed, agility, balance, flexibility, and strength that is affected by the maturity of the child itself [3]. In line with the opinion above, motor development children hand in hand with the growth and maturity of the child physically. The more mature the child's motor development, then the physical state of motion skills are getting stronger and the children will skillfully in accordance with his age.

The capability of performing physical actions and gestures on a child associated with self-confidence and the formation of the self-concept. The formation of these abilities is important for early child in order to foster social developmental as an aspects of early childhood that have to be stimulated early for instilling the ability to socialize and hold connections with friends in their surroundings. Good motor ability forms the concept of the self-image in children that results in their recognition of those surrounding so self-esteem also increases, as in the results of research conducted by Ellerman in 1980 (Suryana et al. 2016).

Based on the results of the findings in the field, the implementation of the development of motor skills in Group B aged 5-6 years at the level close to child development, did physical game with the rules have not been systematically planned and programmed so that the goals will be achieved have not been maximum. The game was dominated by the teacher (teacher centered) so that children got less opportunity to gain diverse stimulus especially their motor ability. This also causes the essence of the game is done less meaningful so that it also affects the child's ability to conduct coordinated movement to train agility, balance, and flexibility of independently.

It is also concerned with the problems of social development of the child in the lesson which was lack stimulation. The level of product development is to comply with the rules that have been made, play with peers and being cooperative on friends. Most children, especially children of the Group B choose aggressively to resolve conflicts so that it will affect the quality of friendship and also affecting children to be cooperative with other friends. In addition, in school, development in terms of social development at the school had minimal variation of learning such as the use of learning 
methods and used other variations such as using traditional games.

The development of the era causing the traditional game is no longer played by society. Games which cultural heritage that must be preserved and the child can learn many things while playing through the game such as traditional social behavior, physical, emotional, and others. The shift in the traditional game into modern technology-based games such as the existence of digital-based games on smart phones, tablets, and play station, reduce the enthusiasm of children to play traditional games. The negative side of modern technologybased games caused children playing passively compared to traditional games.

The statement is proved by results of research by [4] which result children who played with modern technology-based games brought a negative impact on children's behavior when communicating with the people around them. They showed the attitude of selfish, individualist, laziness, violent behavior and affiliative. In addition, they cannot afford to maintain familiarity with friends, indicated by their desire to maintain a low level of togetherness and weak commitment to friendship. In contrast, the traditional game that needs a friend to start the game, making the children have the opportunity to communicate with other children and establish friendship.

Various selections of traditional games and benefits contained can be selected by educators to undertake learning at school. The content of cultural values and local wisdom to make traditional games in each region has the characteristic of each.

One of the many traditional games is a traditional game of jump rope selected for further developed in this research. This game is a game that has simple rules and simple to play for children. The traditional game of jump rope is an easy game played with a simple tool that is a rubber band and used as an obstacle while jumping [5]. This traditional game involves a lot of motor coordination in children so that the children are healthy and have a lot of friends. Help needed to hold the rope while other children play so the children were also developing social. To develop early childhood development aspects of more traditional games, jump rope can be modified in such a way and adapt to the stages of child development. The concept of this traditional game modification refers to the traditional games that already exist are modified to make it more interesting and fun for the child.

Modify a game other than adjusted with child development stages also considering how much of the usability and functionality of the game itself. The function of the traditional game for child development according to the [6] that can stimulate various aspects of its development, e.g. aspects of cognitive, language, emotional, spiritual, ecological, moral values and religion, social and motor skills. Traditional games can support the achievement of the objectives of education as a whole from the domain of cognitive, affective, and psychomotor. A wide range of intelligence can also be stimulated by moving.

The function of the traditional jump rope game among other social attitudes can grow among the players. Children can discuss, socialize about games so that children can learn how to be social and received by the peer. In social attitude, motor developmental aspects particularly gross motor motors can also be honed with the game. Through a combination of a variety of movement jumps, children become increasingly interested and enthusiastic to continue jumping so that it automatically also developed motor ability. The number of functions of the traditional game jump rope on a child's development especially in the development of motor is an important thing for the sake of moving ability to support the child. [7] The importance of the right stimulus on motor development is mainly coarse motor movements affect the ability of the body of a human lifetime.

According to [8], traditional games require the creation and building of social activity in the community so that the game can be called a reflection of traditional cultures around the community. This concept adopted by jump rope game modification that will be modified in terms of instrument playing and game rules. Coordinating the movement of the child can be stimulated in a way that is fun, forming a healthy atmosphere of friendship and togetherness among players, honesty and sportivity all done with great excitement. There are challenges at every level, giving its own impression on the child and challenge children to dare to jump.

This modification of games are part of a legacy of ancestral tradition of the game containing the value of the culture and local wisdom and be able to hone various aspects of child development [5]. The model is a game that flourished in rural communities that are adapted to the local community. From the description above, jump rope games modification is expected to be able to enhance the ability of motor and social skills of children in group B of Kindergarten Dharma Wanita Persatuan Randegansari.

\section{METHOD}

The research design used is ADDIE developed by Dick and Carrey (1996) to design instructional system [9]. This model is an approach that helps instructional designers to create an efficient, effective teaching design by applying the processes of the ADDIE. This model is a design model which is generic and easy to understand. ADDIE stands for Analysis, Design, Development, Implementation, Evaluation. This model can be used for various purposes like development product, model, learning strategies, learning methods, media, and materials described as the following 5 steps.

TABLE. 1. STEPS OF ADDIE MODEL

\begin{tabular}{|c|c|}
\hline Steps & Activity \\
\hline Analysis & $\begin{array}{l}\text { Clarifies the instructional } \\
\text { problems and objectives, } \\
\text { and identifies the learning } \\
\text { environment and learner's } \\
\text { existing knowledge and } \\
\text { skills. } \\
\text { Identify the problems of } \\
\text { motor and social skills of the } \\
\text { children, determine what } \\
\text { skill and knowledge children }\end{array}$ \\
\hline
\end{tabular}




\begin{tabular}{|c|c|}
\hline & $\begin{array}{l}\text { need in achieving the goals, } \\
\text { identify children } \\
\text { characteristics aged } 5-6 \\
\text { years and materials what } \\
\text { needs. }\end{array}$ \\
\hline Design & $\begin{array}{l}\text { The design phase deals with } \\
\text { learning objectives, } \\
\text { assessment instruments, } \\
\text { exercises, content, subject } \\
\text { matter analysis, lesson } \\
\text { planning, and media } \\
\text { selection. } \\
\text { Preparing of the learning } \\
\text { objectives, designing game, } \\
\text { compile the design } \\
\text { assessment instruments }\end{array}$ \\
\hline Development & $\begin{array}{l}\text { Creating and developing } \\
\text { jump rope modification } \\
\text { design, the blueprint design } \\
\text { jump rope modification } \\
\text { reviewed by expert review } \\
\text { and did revision }\end{array}$ \\
\hline Implementation & $\begin{array}{l}\text { Implementing trial of the } \\
\text { jump rope modification on } \\
\text { the Group B of the } \\
\text { Kindergarten } \\
\text { Randegansari for } 6 \text { meetings } \\
\text { for small group trial, large } \\
\text { and field trial }\end{array}$ \\
\hline Evaluation & $\begin{array}{l}\text { Evaluate which serves as a } \\
\text { benchmark the extent to } \\
\text { which the level of } \\
\text { achievement of the motor } \\
\text { and social skills } \\
\text { development of the child } \\
\text { group B against the } \\
\text { traditional jump rope game } \\
\text { modifications are made. }\end{array}$ \\
\hline
\end{tabular}

The data collection techniques used in this study were observation, interview, documentation, and questionnaire. Expert review used a questionnaire given to a media expert and subject matter expert. Small trial was with observation and interview sheets for 8 children of group B. Large group trial was with interview and observation sheet for 16 children of group B. A validation and game expert and a summative evaluation of field test obtained quantitative data and field trials used experiments with observation sheets to compare motor and social skills at pretest and posttest scores for 28 of group B.

\section{RESULT AND DISCUSSION}

Finally, the results of data analysis development of the jump rope games modification media for children showed the trial result feasibility of the experts and group trials, showed effectiveness in learning and increasing ability to develop motor and social skills development proven through the test results. The results of the trial can be seen in the following table.
TABLE. 2. RESULT OF EXPERT ADJUSTMENT AND FIELD TRIAL

\begin{tabular}{|l|l|l|}
\hline \multicolumn{1}{|c|}{ Validation } & \multicolumn{1}{|c|}{$\%$} & \multicolumn{1}{c|}{ Revision } \\
\hline Material expert & $95.57 \%$ & $\begin{array}{l}\text { Games tool: jump rope } \\
\text { with variation }\end{array}$ \\
\hline Media expert & $95.25 \%$ & $\begin{array}{l}\text { Simplified rules (4-5 } \\
\text { rules) }\end{array}$ \\
\hline Small group trial & $97.25 \%$ & Additional safety stuff \\
\hline Large group trial & $98.35 \%$ & $\begin{array}{l}\text { Advisable to use with } \\
\text { no revision }\end{array}$ \\
\hline Field Trial & $98.35 \%$ & $\begin{array}{l}\text { Advisable to use with } \\
\text { no revision }\end{array}$ \\
\hline
\end{tabular}

The result of data analysis on field trial using pairedsamples t-test showed the mean difference between pretest i.e. 20.43. The test participants were $\mathrm{N}=28$; Standard deviation $=$ 1.913 and mean posttest equal to 25.29; The test participants were $\mathrm{N}=28$; Standard deviation $=1.761$.

Correlation between pretest and posttest was equal to .0705 with significance level of 0.026 . Based on the analysis results, it was obtained sig value of 0.026 , where the value of $\alpha=0.05$ is greater than sig. Then $\mathrm{H} \alpha$ is accepted and Ho is rejected. This means that there are differences in learning outcomes after played jump rope games modified for motor and social skills has been developed.

\section{CONCLUSION}

Based on the result of data analysis it can be said that there was a difference in the average value of pretest and posttest score in the learning process of motor skill of social through jump rope game modification. After jumped, the social development of children will also be met when the child must support a friend to be able to jump over the level so that the points of the ball can reach the maximum value. The advantages of the jump rope game are easy to play, challenging, the equipment is cheap and easy to create, nourish and one simple game that can be done by children up to adults.

In addition, this research provides an efficient idea how to enhance motor and social skills combined cultural values that embodied in this game through jump rope game modification. The culture values contain values of hard work, agility, accuracy, and sportive.

This study is in accordance with research conducted by Vygotsky [10] mention that actively, children build understanding and knowledge through social interaction with others. The interaction processes help early child how path perspective of others and able to have contributed to the view of others against certain situations so that they are more cooperative, sportive, and easier to follow the rules.

\section{References}

[1] Y. N. Sujiono, "Konsep dasar PAUD," Jakarta: Indeks, 2009.

[2] R. A. Hawadi, "Psikologi perkembangan anak," Jakarta: PT. Grasindo, 2001 . 
[3] M. Adriani and B. Wirjatmadi, "Gizi dan Kesehatan Balita Peranan Mikro Zinc pada Pertumbuhan Balita," Jakarta: Kencana, 2014

[4] S. B. Lestari and A. Naryoso, "Memahami Pengalaman Komunikasi Antarpribadi Anak Berkaitan dengan Perubahan Kebiasaan Bermain Permainan Tradisional Menjadi Permainan Modern Berbasis Teknologi (Studi pada Anak-anak di Dukuh Paren, Kelurahan Sidomulyo, Kecamatan Ungaran Timur, Kabupaten S," Interaksi Online, vol. 1, 2013.

[5] N. Mulyani, "Super asyik permainan tradisional anak indonesia," ed: Yogyakarta: Diva Press, 2016.

[6] H. Nur, "Membangun karakter anak melalui permainan anak tradisional," Jurnal Pendidikan Karakter, 2013
[7] S. D. Sunaryo, "Intervensi Dini Anak Berkebutuhan Khusus," ed: Jakarta: Departemen Pendidikan Nasional, 2007.

[8] N. N. Seriati and N. Hayati, "Permainan Tradisional Jawa Gerak dan Lagu Untuk Menstimulasi Keterampilan Sosial Anak Usia Dini," Naskah Publikasi, 2012.

[9] W. Dick, "The Dick and Carey model: Will it survive the decade?," Educational technology research and development, vol. 44, pp. 55-63, 1996.

[10] J. W. Santrock, "Life-Span Development: Perkembangan Masa Hidup (edisi kelima).(Penerj. Achmad Chusairi, Juda Damanik; Ed. Herman Sinaga, Yati Sumiharti)," Erlangga. Jakarta, 2002. 